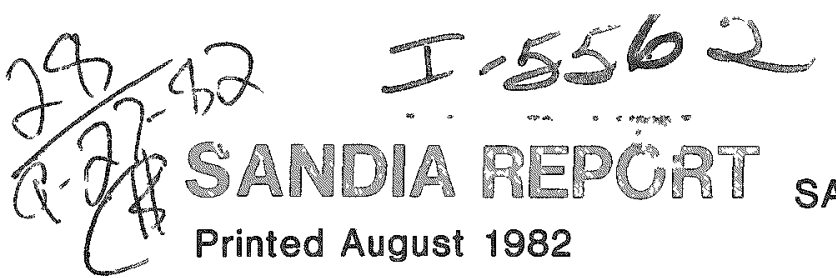

SAND82-0819 - TTC-0298 - Unlimited Rẽleäsé - UC-71

. SAID $-82-0819$

\title{
Shock and Vibration Environments Encountered During Normal Rail Transportation of Heavy Cargo
}

0802022238

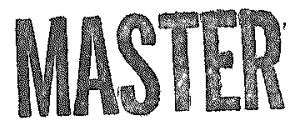

Clifford F. Magnuson

\section{Prepared by}

Sandia National Laboratories

Albuquerque, New Mexico 87185 and Livermore, California 94550

for the United States Department of Energy

under Contract DE-ACO4-76DP00789 


\section{DISCLAIMER}

This report was prepared as an account of work sponsored by an agency of the United States Government. Neither the United States Government nor any agency Thereof, nor any of their employees, makes any warranty, express or implied, or assumes any legal liability or responsibility for the accuracy, completeness, or usefulness of any information, apparatus, product, or process disclosed, or represents that its use would not infringe privately owned rights. Reference herein to any specific commercial product, process, or service by trade name, trademark, manufacturer, or otherwise does not necessarily constitute or imply its endorsement, recommendation, or favoring by the United States Government or any agency thereof. The views and opinions of authors expressed herein do not necessarily state or reflect those of the United States Government or any agency thereof. 


\section{DISCLAIMER}

Portions of this document may be illegible in electronic image products. Images are produced from the best available original document. 
Issued by Sandia National Laboratories, operated for the United States Department of Fnergy by Sandia Corporation.

NOTICE: This report was prepared as an account of work sponsored by an arency of the United States Government. Neither the United States Government nor any agency thereot, nor any of their ermployees, nor any of their contractors, subeontractors, or their employees, makes any warranty, express or implied, or assumes any legal liability or responsibility for the accuracy, completeness, or usefulness of any information, apparatus, product, or process disclosed, or represents that its use would not infringe privately owned rights. Reference herein to any specific commercial product, process, or nervice by trade name, trademarl, manufacturer, or otherwige, does not service by trade name, trademark, manuiacturer, or otherwise, does not necessarily constitute or imply its endorsement, recommendation, or favoring
by the United States Government, any agency thereof or any of their contractors or subcontractors. The views and opinions expreased herein do not necessarily state or reflect those of the United States Government, any agency thereof or any of their contractors or subcontractors.

Printed in the United States of America Avalable from

National Technical Information Service

U.S. Department of Commerce

5285 Port Roval Road

Springtield, VA 22161

NTIS price codes

Printed copy: A02

Microfiche copy: A01 


\section{Shock and Vibration Environments Encountered During Normal Rail Transportation of Heavy Cargo}

Clifford F. Magnuson

Applied Mechanics Division III, 5523

Sandia National Laboratories

Albuquerque, NM 87185

Prepared for

Transportation Technology Center

Sandia National Laboratories

Albuquerque, NM 87185

\section{Abstract}

This study was conducted to obtain vibration and superimposed shock data during normal rail shipment of heavy cargo. The data were obtained during a regularly scheduled rail shipment of a 45-tonne (50-ton) cargo which consisted of an empty spent-fuel container, its supporting structure, and associated hoisting devices. The shipment was made over rail lines which are operated by the Atchison, Topeka, and Santa Fe Railway Company between Denver, Colorado and Albuquerque, New Mexico. The instrumented rail car was equipped with $0.38-\mathrm{m}$ (15-in.) hydraulic endof-car coupling devices. The 99 percentile levels of vibration acceleration amplitudes and single degree-of-freedom superimposed shock response spectra for the longitudinal, transverse, and vertical axes are presented.

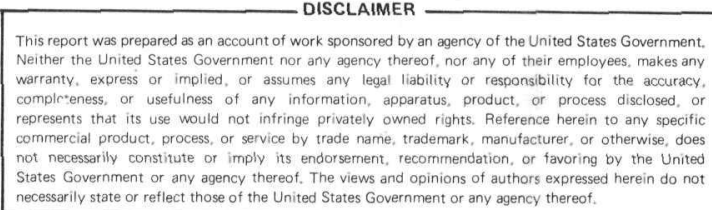




\section{Acknowledgments}

In addition to M. B. Gens and R. C. Rentzsch, SNL, who participated in the instrumentation and data gathering, my thanks to the following persons who participated in and/or supported this project: W. N. Spears, J. W. Donalson, and R. Smith, AT\&SF, Albuquerque, NM, and W. Purchase, DOE/ALO for their efforts during the planning and scheduling. $W$. H. Clark, Applied Research Assistant Manager, AT\&SF, Topeka, KS; F. L. Sparks, Road Foreman, AT\&SF, Pueblo, CO; S. L. Fruin, Road Foreman, AT\&SF, La Junta, CO; H. G. Powers, Trainmaster, AT\&SF, Raton, NM; and the engineers on the trains involved in the test for their assistance during the data gathering operation. R. W. Cecil and J. Lewis, Stearns-Roger, Denver, $\mathrm{CO}$, for their cooperation during the loading of the test rail car and the installation of the instrumentation. 


\section{Contents}

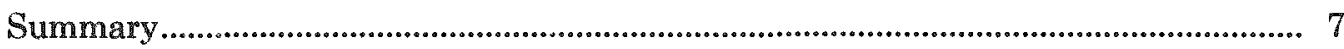

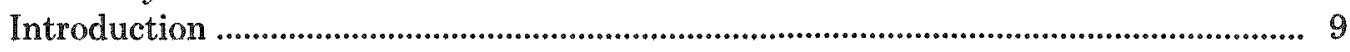

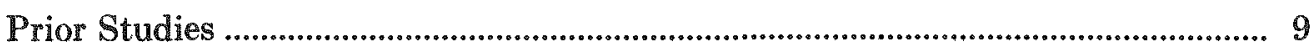

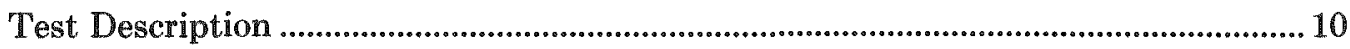

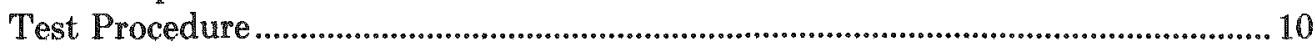

Train Configuration ............................................................................................................ 11

Instrumented Rail Car .................................................................................................... 11

Cargo Tiedowns ................................................................................................................ 11

Data Acquisition ...................................................................................................... 12

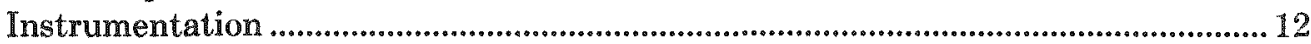

Test Results................................................................................................................. 16

Definitions of Dynamic Environments ............................................................... 16

Explanation of Data ............................................................................................................. 16

Data Reduction ........................................................................................................ 16

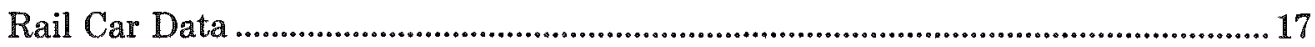

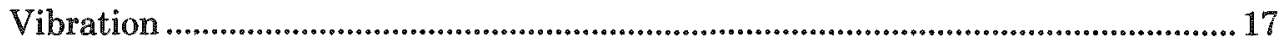

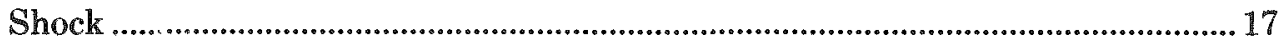

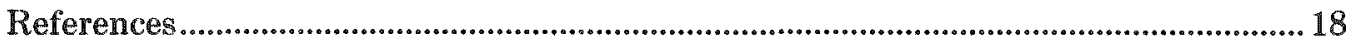

\section{Figures}

1 Rail Car and Cargo Before Protective Cover in Place ......................................... 10

2 Cargo Tiedown and Blocking; Protective Cover in Place .................................... 11

3 Accelerometer Mounting Over Forward Bolster ................................................... 13

4 Accelerometer Mounting at Middle of Rail Car ................................................. 14

5 Accelerometer Mounting Over Rear Bolster Showing Data Acquisition System ............................................................................................................... 15

6 Rail Vibration-Input to Cargo (g) 99 Percentile Level of Zero-to-Peak Amplitudes ............................................................................................................. 17

7 Mean Plus Three Standard Deviation Amplitude Envelopes of Shock Response Spectra; $3 \%$ Damping 


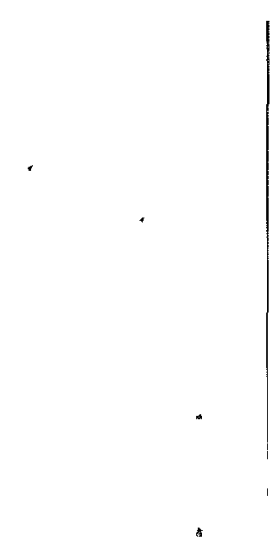




\section{Summary}

Shock and vibraton environments were measured during rail transport of a 45-tonne (50-ton) cargo mounted on a railroad flat car. The cargo was transported by regular railroad methods from Denver, Colorado to Albuquerque, New Mexico.

The maxima of the 99 percentile levels of acceleration amplitude vibration for a 45-tonne (50-ton) cargo over the frequency range of 0 to $750 \mathrm{~Hz}$ were

\begin{tabular}{lc}
\hline \multicolumn{1}{c}{ Axis } & $\begin{array}{c}\text { Zero-to-Peak } \\
\text { Acceleration (g) }\end{array}$ \\
\hline Longitudinal & 0.10 \\
Transverse & 0.19 \\
Vertical & 0.52 \\
\hline
\end{tabular}

The shock response spectra, using $3 \%$ damping, are shown in the following figure.

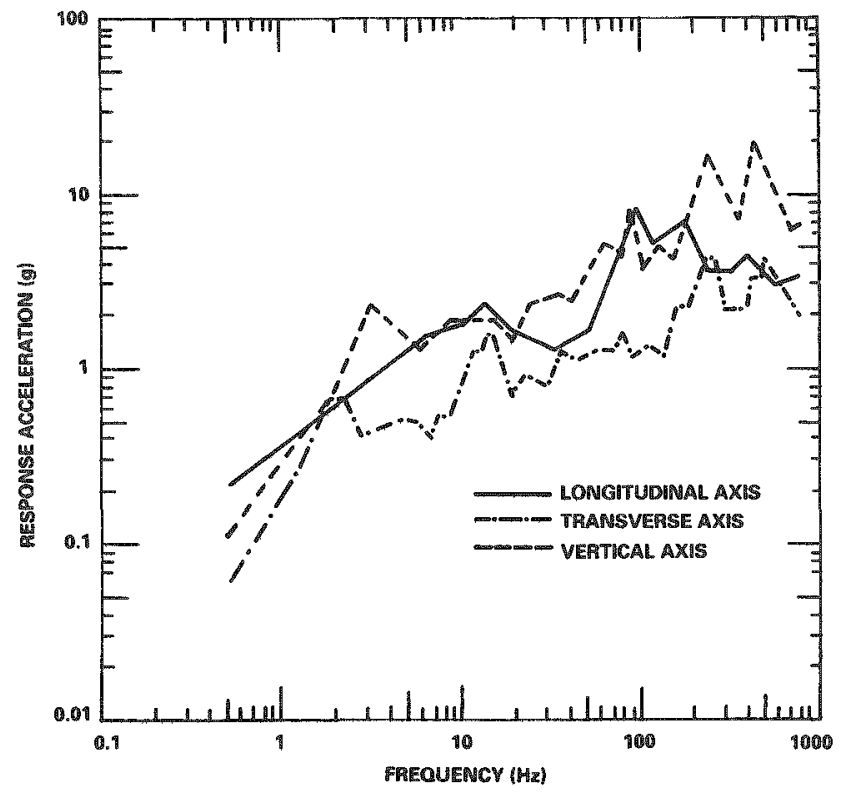

Mean Plus Three Standard Deviation Amplitude Envelopes of Shock Response Spectra; 3\% Damping 


\section{Shock and Vibration Environments Encountered During Normal Rail Transportation of Heavy Cargo}

\section{Introduction}

The packaging and transportation of fissile radioactive materials are regulated by the US Nuclear Regulatory Commission (NRC) by means of Federal Regulations Title 10, Part 71. Appendix A of these regulations specifies that the environmental conditions of transport be applied to determine their effects on packages of radioactive material. However, the appendix does not quantify the frequencies or amplitudes of vibration and shock environments, nor does it give their expected occurrence rate as a function of shipment time and/or mileage. As a result, when evaluating a package for licensing application, assumptions regarding the intensities of these environments must be made by each applicant.

Shock and vibration data were available for rail transport of 14 tonne (15 ton) cargo. Spent fuel shipping containers often weigh more than this, so data needed to be obtained during rail transport of heavier cargo. The investigation described in this report results in descriptions of shock and vibration for cargo weighing 45 tonnes (50 tons).

All data described in this report were taken in English units. The metric (SI) values presented result from rounding the English units to the nearest SI units.

\section{Prior Studies}

Sandia National Laboratories (SNL) has conducted other investigations to gather and evaluate data on the shock and vibration environments normally encountered during transport of heavy shipping containers by both rail and truck. These investigations were conducted under contract to the NRC.

Efforts in these areas to date have consisted of the following artivities:

- Transportation shock and vibration data available up to 1975 in the Department of Energy
(DOE)/Department of Defense (DoD) and the DOE transportation data banks were reviewed and are reported in Reference 1. Predictions of the influence of heavier cargo on these environments as well as predictions of the influence of shock-attenuating couplers on rail cars also were reported in Reference 1 . These predictions were based on analytical studies.

Truck data were based on cargo weights which varied from no-load to 14 tonnes ( 15 tons). Overthe-road rail data were based on a cargo weight of 14 tonnes ( 15 tons). Rail coupling-shock data were based on cargo weighing approximately 5 tonnes (5 tons).

- Data were gathered during truck transport of two spent-fuel shipping containers. One weighed 20 tonnes (22 tons) and the other weighed 25 tonnes (28 tons). These containers were transported over existing highways between Mercury, Nevada and Albuquerque, New Mexico. The definitions of the shock and vibration environments measured during these events were reported in References 2 and 3. Comparisons of the three sets of truck data are presented in Reference 3.

- Data were gathered during rail-coupling test operations conducted at the Savannah River Plant with cargo weighing 36 tonnes ( 40 tons) and 64 tonnes (70 tons). The impacting end of each instrumented rail car was equipped with a standard draft gear, a $0.38-\mathrm{m}(15$-in. $)$ hydraulic end-of-car device, and a $0.51 \mathrm{~m}$ (20-in.) sliding center-sill cushion underframe. Impact velocity during these tests ranged from $4.44 \mathrm{~km} / \mathrm{hr}(2.76$ $\mathrm{mph})$ to $17.98 \mathrm{~km} / \mathrm{hr}(11.17 \mathrm{mph})$. The data resulting from these tests are reported in Reference 4. 


\section{Test Description}

The test described in this report was conducted to obtain vibration and shock data which were superimposed on vibration data during regular rail shipment of cargo that was heavier than 14 tonnes (15 tons).

\section{Test Procedure}

This test was conducted during a regularly scheduled rail shipment of 45 -tonne (50-ton) cargo over rail lines between Denver, Colorado and Albuquerque,
New Mexico. These lines are operated by the Atchison, Topeka, and Santa Fe (AT\&SF) Railway Company. The cargo consisted of an empty spent-fuel shipping container and skid along with the necessary hoisting devices. The cargo and rail car are shown in Figure 1 before a protective cover was placed over the spent-fuel container. An additional caboose was provided by AT\&SF for SNL and AT\&SF personnel who were involved in the test. This caboose was always adjacent to and immediately behind the instrumented rail car and immediately in front of the caboose which was occupied by the train crew at the rear of the train. The trains involved in the tests were those regularly operated by AT\&SF for freight service.

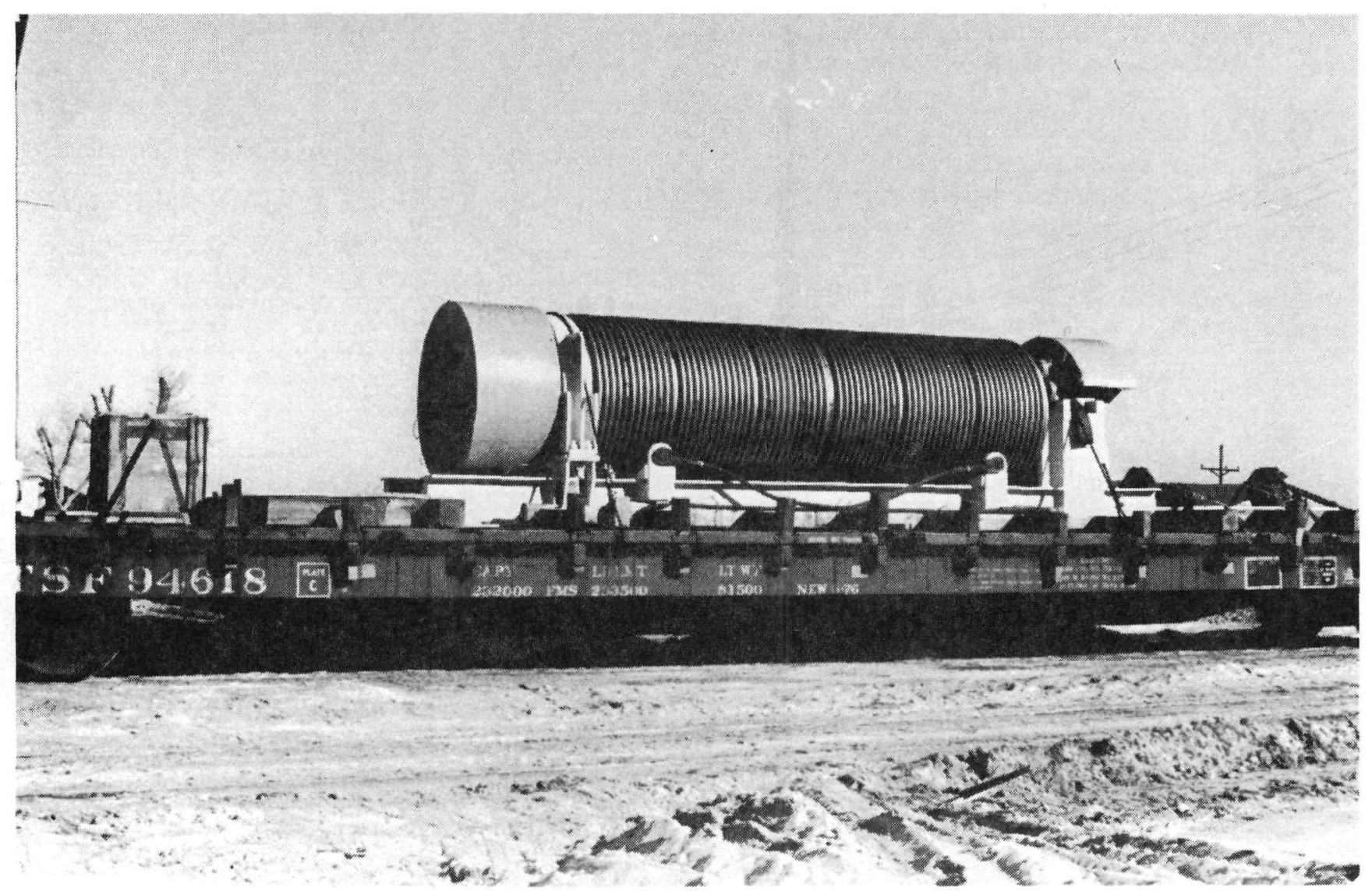

Figure 1. Rail Car and Cargo Before Protective Cover in Place 


\section{Train Configuration}

Three separate trains were used during this test. The AT\&SF 495 Extra South was used between Denver, Colorado and Pueblo, Colorado; it consisted of 43 cars having a total weight of 2603 tonnes (2869 tons) and was pulled by two diesel locomotives.

AT\&SF 403 was used between Pueblo, Colorado and La Junta, Colorado; it consisted of 26 loaded rail cars and 27 empty rail cars. The total weight of Train 403 was 3397 tonnes (3744 tons). It was pulled by two diesel locomotives. There were two additional locomotives in the train that were not used for power; they were immediately behind the powered locomotives.

AT\&SF 408 was used between La Junta, Colorado and Albuquerque, New Mexico; it consisted of 27 loaded rail cars and 19 empty rail cars from La Junta, Colorado to Trinidad, Colorado. The total weight of this train was 3154 tonnes (3477 tons). Nine additional loaded cars were attached at Trinidad, Colorado; the total weight of the train from Trinidad, Colorado to Albuquerque, New Mexico was 4173 tonnes (4600 tons). Train 408 was configured for mountainous terrain in that six locomotives were used. Four of the six locomotives were on the front of the train and were followed by loaded rail cars except for the instrumented rail car. The loaded rail cars were followed by two diesel locomotives controlled remotely by the engineer in the lead locomotive. The remote locomotives were followed by the 19 empty rail cars, the instrumented rail car, and the 2 cabooses.

\section{Instrumented Rail Car}

The rail car on which cargo and instrumentation were loaded was AT\&SF Flat Car 94618. The car was manufactured by Thrall. It was $21 \mathrm{~m}$ (68 ft) long, weighed 37 tonnes (41 tons), and had a normal capacity of 105 tonnes (116 tons) and a maximum capacity of 106 tonnes (117 tons). It was equipped with trucks having two axles each and had wheels which were $1 \mathrm{~m}$ (38 in.) in diameter. The couplers were equipped with $0.38-\mathrm{m}(15$-in.) hydraulic end-of-car devices. The cargo floor was wood. The A-end of the car was forward during the entire shipment.

\section{Cargo Tiedowns}

The spent-fuel shipping container was tied to the instrumented rail car by two cables. Longitudinal and transverse motion was prevented by wood blocking (Figure 2).

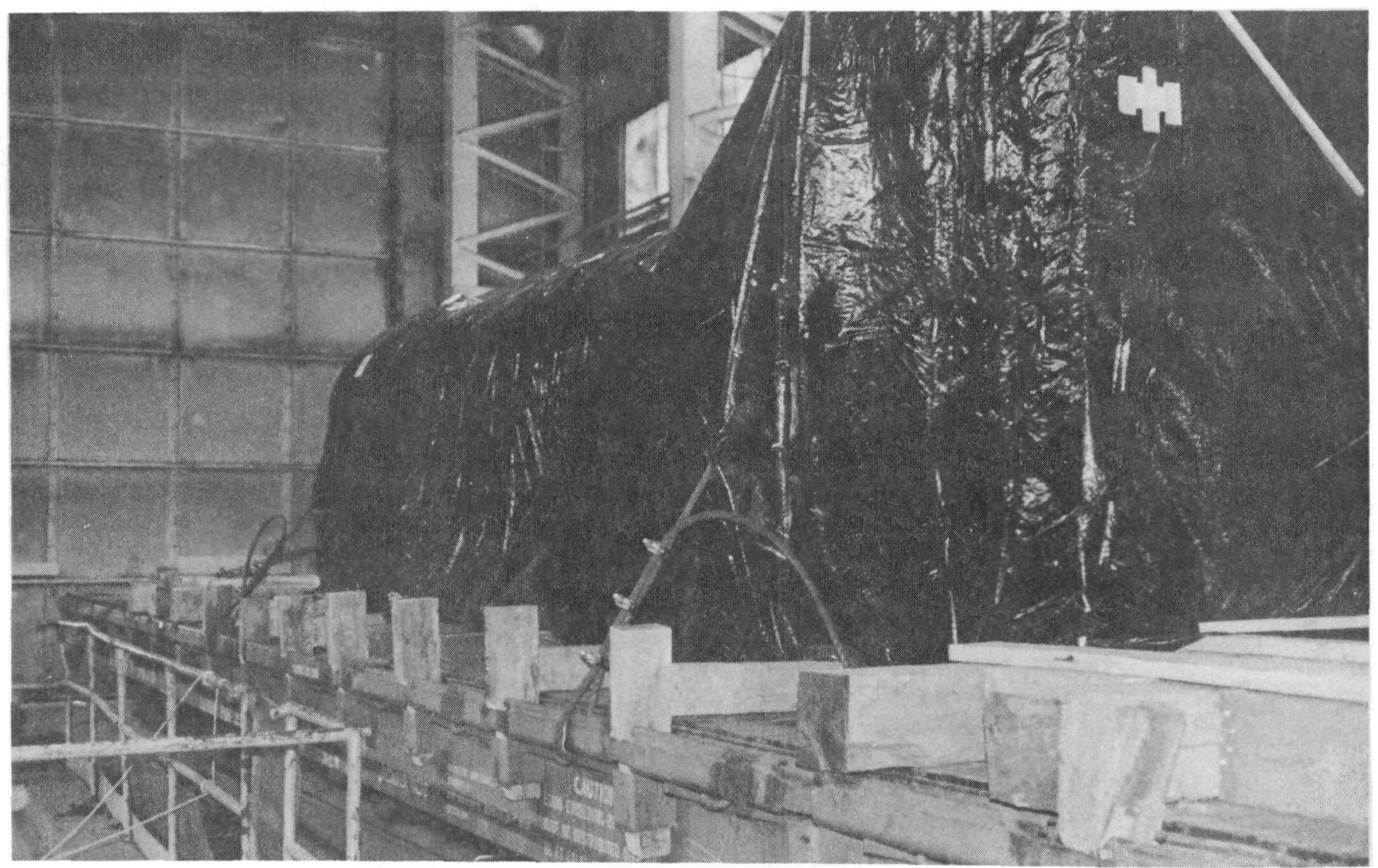

Figure 2. Cargo Tiedown and Blocking; Protective Cover in Place 


\section{Data Acquis $\mathrm{h}^{\mathrm{T}}$ ion}

Data measurements were obtained on a sampling basis. The data acquisition system was started and stopped remotely by SNL personnel in the caboose immediately to the rear of the instrumented rail car when the desired sampling locations were encountered. Sampling locations had been preselected by SNL personnel based on detailed track charts provided by AT\&SF. Some of the sampling locations were changed during the test because of suggestions made by the AT\&SF operational personnel who were participating in the test and were in the caboose with SNL personnel. AT'\&SF personnel had been briefed on the types of events to be sampled (coupler slack take-up (run-in or buff and run-out or draft), switches, road crossings, climbs, descents, flat track, undulating track, and rough track], and with their knowledge of local track conditions and how trains react to terrain variations, they were able to provide suggestions as to where such data samples could be obtained.

Train speeds were obtained from the train engineers while data samples were being taken.

\section{Instrumentation}

The instrumentation consisted of accelerometers with their associated cabling and a data acquisition system which was designed and fabricated at SNL. The data acquisition system contained the necessary signal conditioning equipment and a tape recorder to provide an analog record of the output from the accelerometers. The system was started and stopped remotely by radio link, so that data sampling was controlled by SNL personnel who were riding in the caboose immediately behind the instrumented rail car.

Fourteen data channels were available on the data acquisition system. One channel was used to record IRIG time being generated by the system. By synchronizing a digital watch with the time generator, specific segments on the data tape were identified with specific events for data reduction purposes by recording the IRIG time and the event conditions during each event on event identification sheets. One channel was used as a noise-identification channel. Twelve channels were used to record the excitations being experienced by the accelerometers.

Eleven piezoresistive accelerometers having a frequency capability of 0 to $750 \mathrm{~Hz}$ and one piezoelectric accelerometer with a frequency capability of 3 to 2500 $\mathrm{Hz}$ were mounted on the rail car structure to measure the input from the rail car to the cargo. All of the accelerometers were mounted onto drilled and tapped 1 -in. aluminum cubes. The cubes were attached to the rail car structure by dental cement. This method of mounting the accelerometers did not require any drilling and tapping of the rail-car structure. The resonant frequency of this mounting method is approximately $4000 \mathrm{~Hz}$, which is well above the highest frequency of the instrumentation used.

Three piezoresistive accelerometers were mounted over the trucks on the forward end of the rail car to measure the excitations in the longitudinal (forward and aft), transverse (left and right), and vertical axes (Figure 3). Three piezoresistive accelerometers oriented to measure excitations in the longitudinal, transverse, and vertical axes were mounted on the lower flange of a longitudinal structural member (Figure 4) near the middle of the rail car.

Five piezoresistive and one piezoelectric accelerometer along with an inert accelerometer for noise detection were mounted over the trucks on the aft end of the rail car. These accelerometers and the data acquisition system are shown in Figure 5 . Three of the five piezoresistive accelerometers mounted over the rear trucks were oriented to measure excitations in the longitudinal, iransverse, and vertical axes. Two of the piezoresistive accolerometers at the rear position were oriented to measure excitations in the longitudinal and vertical axes. These two accelerometers were calibrated at higher amplitude levels than the others to provide data if the others overranged during an event. The piezoelectric accelerometer was mounted to measure excitations in the vertical axis. This accelerometer was included in the instrumentation to provide an indication of any significant excitation above the 750 $\mathrm{Hz}$ capability of the piezoresistive accelerometers. 


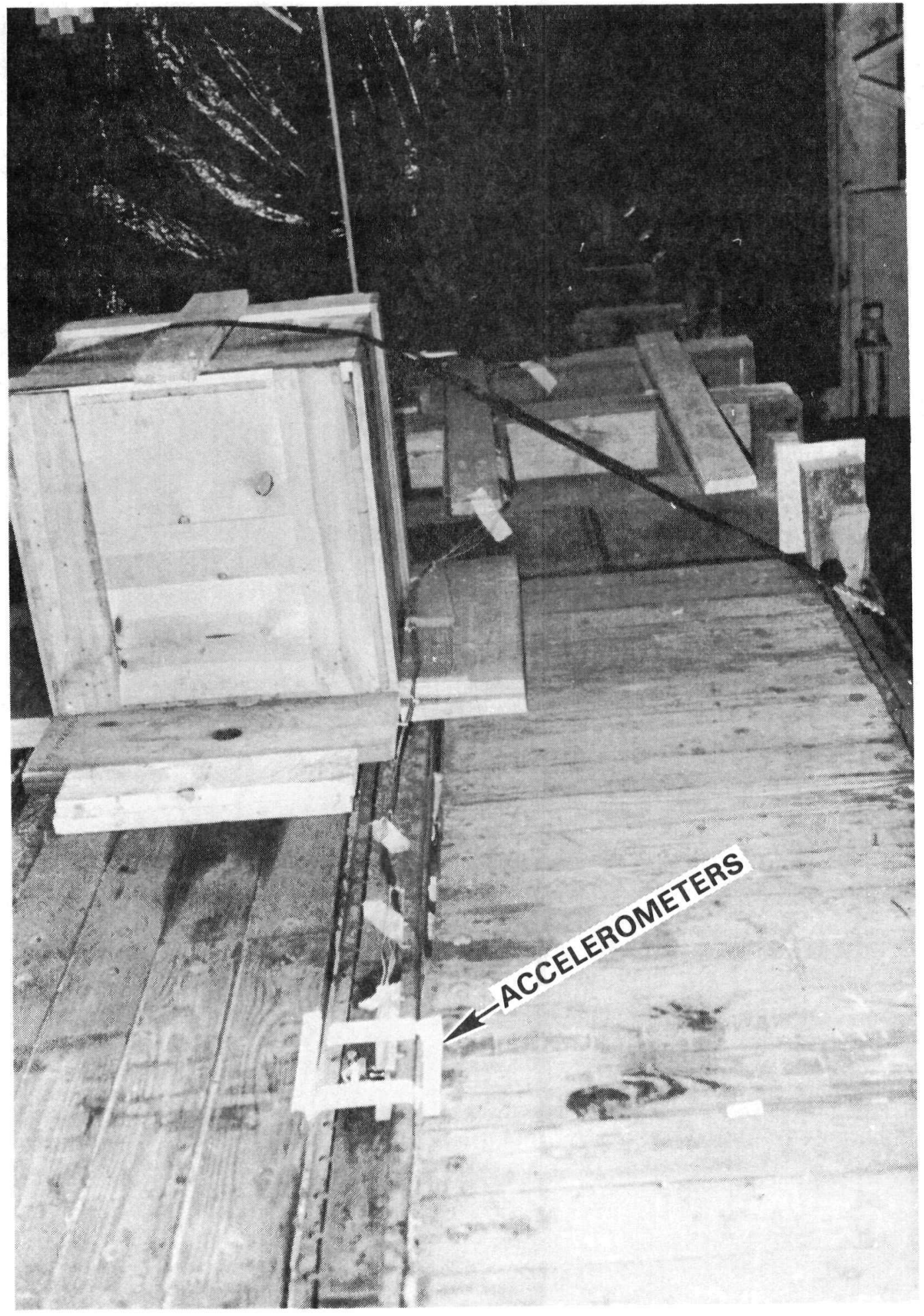

Figure 3. Accelerometer Mounting Over Forward Bolster 


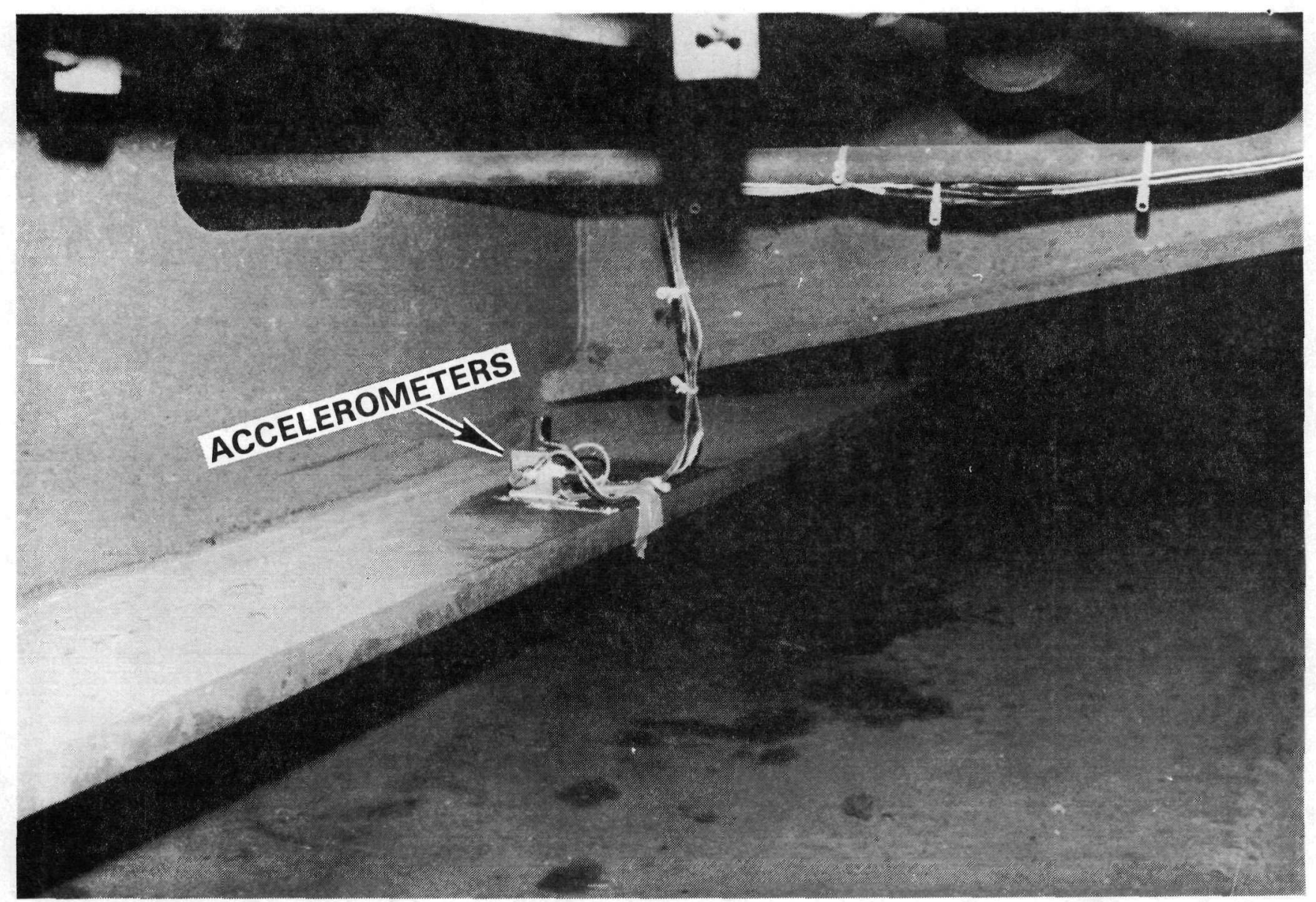

Figure 4. Accelerometer Mounting at Middle of Rail Car 


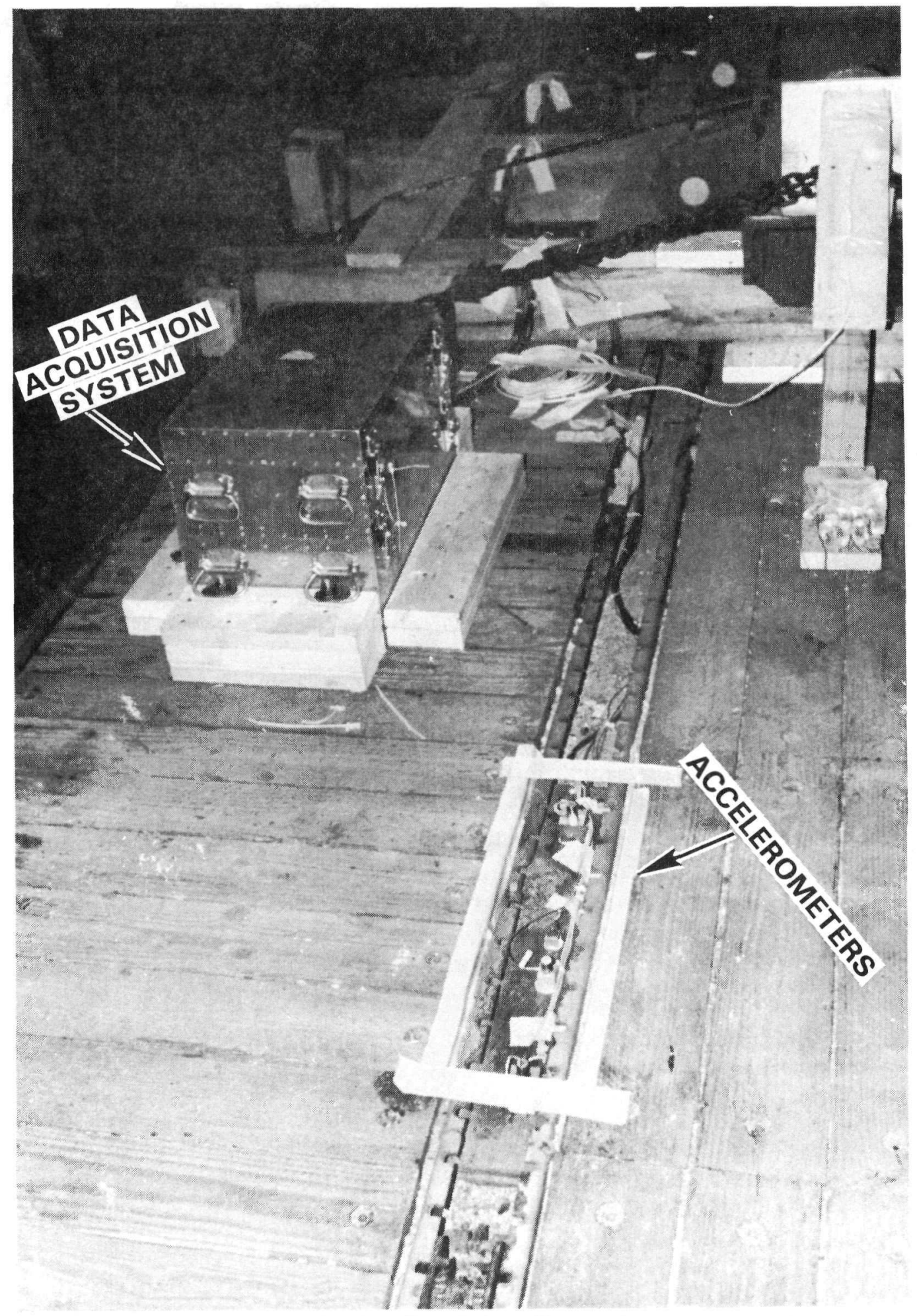

Figure 5. Accelerometer Mounting Over Rear Bolster Showing Data Acquisition System 


\section{Test Results}

The environmental descriptions presented in this section summarize the data obtained during the rail shipment of a 45-tonne (50-ton) cargo from Denver, Colorado to Albuquerque, New Mexico.

\section{Definitions of Dynamic}

\section{Environments}

Dynamic excitations delivered to cargo may be described as a mixture of vibration, occasional shock superimposed on the vibration, and shock that occurs in single isolated events such as rail coupling.

Vibration, the excitation that occurs whenever the carrier is in motion, is produced by the carrier's suspension system and frame members reacting to surface and/or wheel irregularities.

Superimposed shock is that short-duration excitation which often results in higher excitation amplitudes than those produced by vibration. This excitation results from specific occurrences during travel. Typical occurrences are (1) run-in; (2) run-out; and (3) crossing bridges, switches, and automobile cross roads. Characteristically, these excitations consist of decaying transient pulses intermixed with the vibration.

This report presents data fitting the above definitions only. Shock resulting from rail-coupling operations are reported in Reference 4.

\section{Explanation of Data}

The vibration data presented are zero-to-peak acceleration amplitude levels that include at least $99 \%$ of all amplitudes measured in each frequency band. The distribution of acceleration amplitudes in each frequency band is random, for which the probability distribution is nearly gaussian. This makes the reported amplitude levels approximately the threesigma amplitude levels of excitations.

The superimposed shock data presented were reduced in single degree-of-freedom response spectra format. These spectra predict the maximum acceleration amplitudes to which single degree-of-freedom systems would respond when subjected to the complex transient pulse inputs. Response spectra were used because they permitted translation of complex input excitations into a more useful engineering format and permitted statistical summarization of different individual excitations. In generating these response spectra, $3 \%$ damping was used because experience has shown this to be representative of most hard-mounted systems.

\section{Data Reduction}

The data samples were recorded on magnetic tapes during shipment. An oscillograph record of all data tapes was produced to correlate specific events with the associated data tape segments to be used for data reduction. The events were identified for data reduction as either vibration or shock. Vibration data were reduced by data reduction program VIBRAN. ${ }^{6}$ This program counts the number of zero-to-peak acceleration amplitudes in predetermined amplitude ranges in preselected frequency bands. After the VI$B R A N$ records were available, appropriate records were combined into composite records by program VAIL. ${ }^{7}$ The VAIL program combines VIBRAN records and displays the resulting distribution of zeroto-peak amplitudes in the same format as the individual VIBRAN records.

The shock records were reduced in response spectra format. The individual response spectra were then combined using program ZSHAIL. This program produces new spectra which show (1) an estimate of the mean response spectrum of the spectra being combined, (2) the peak acceleration of all the records combined, and (3) the estimated mean plus three standard deviations at discrete frequencies. The estimate of the standard deviation at each frequency is equal to

$\hat{\sigma}=\left[\frac{\Sigma x^{2}-\frac{(\Sigma \Psi)^{2}}{n}}{n-1}\right]^{1 / 2}$,

where

$\mathrm{x}=$ acceleration amplitude at a discrete frequency

$\mathrm{n}=$ number of records being combined.

Recorded measurements from thirteen events were selected for data reduction for vibration descriptions. These events included flat track, undulating track, rough track, climbs, descents, curves, and multiple highway grade crossings. Train speeds during these events were between 40 and $89 \mathrm{~km} / \mathrm{hr}$ ( 25 and 55 $\mathrm{mph}$ ).

Recorded measurements from sixteen events were selected for data reduction for superimposed shock descriptions. These events included (1) run-in; (2) run-out; and (3) crossing switches, bridges, automobile cross roads, and a highway underpass. Train speeds during these events varied between 31 and 89 $\mathrm{km} / \mathrm{hr}$ (19 and $55 \mathrm{mph}$ ). 


\section{Rail Car Data}

\section{Vibration}

The vibration data presented herein are summaries of the cumulative zero-to-peak acceleration amplitude levels which include at least $99 \%$ of all accelerations measured in each frequency band. The summaries include data from all three accelerometer locations and represent a generic definition of input to cargo.

The highest of the cumulative $99 \%$ levels of zeroto-peak acceleration amplitudes occurred in the vertical axis across the entire frequency spectrum between 0 and $750 \mathrm{~Hz}$. The vertical acceleration amplitudes were generally at or below $0.37 \mathrm{~g}$ except between 240 and $300 \mathrm{~Hz}$ where the acceleration amplitude was 0.52 g. Study of random vibration data which were reduced show that in this frequency band the concentration of energy was at approximately $250 \mathrm{~Hz}$.

The vibration zero-to-peak acceleration amplitude levels in the transverse axis were equal to or higher than those in the longitudinal axis. The highest acceleration amplitude levels were $0.19 \mathrm{~g}$ in the 0 - to 5 and $10-$ to $20-\mathrm{Hz}$ frequency bands for the transverse axis and $0.10 \mathrm{~g}$ in the 180 - to $240-$ and 500 - to $750-\mathrm{Hz}$ frequency bands in the longitudinal axis. Figure 6 is a histogram of the acceleration amplitude levels of vibration in all three axes. Details of the 99 percentile levels of zero-to-peak acceleration amplitudes in each frequency band and for each axis are given in Table 1.

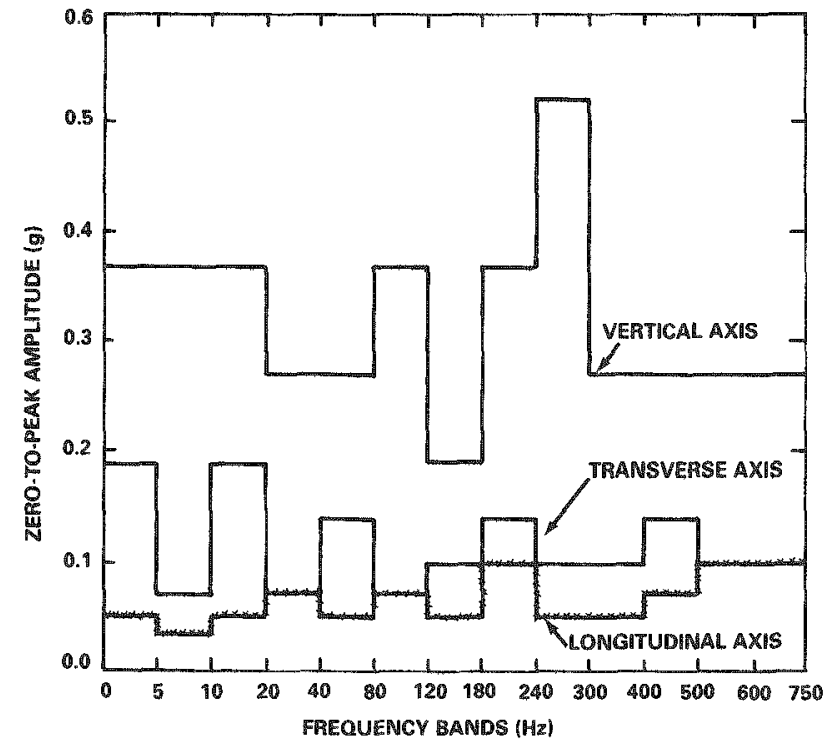

Figure 6. Rail Vibration-Input to Cargo (g) 99 Percentile Level of Zero-to-Peak Amplitudes
Table 1. Rail Vibration for 45-Tonne (50-Ton) Cargo

Input to Cargo at 99 Percentile Level of Zero-to-Peak Amplitude (g)

\begin{tabular}{|c|c|c|c|}
\hline $\begin{array}{l}\text { Frequency } \\
\text { Band }(\mathrm{Hz})\end{array}$ & $\begin{array}{l}\text { Longitudinal } \\
\text { Axis } \\
\end{array}$ & $\begin{array}{c}\text { Transverse } \\
\text { Axis } \\
\end{array}$ & $\begin{array}{l}\text { Vertical } \\
\text { Axis }\end{array}$ \\
\hline $0-5$ & 0.052 & 0.190 & 0.37 \\
\hline $5-10$ & 0.037 & 0.072 & 0.37 \\
\hline $10-20$ & 0.052 & 0.190 & 0.37 \\
\hline $20-40$ & 0.072 & 0.072 & 0.27 \\
\hline $40-80$ & 0.052 & 0.140 & 0.27 \\
\hline $80-120$ & 0.072 & 0.072 & 0.37 \\
\hline $120-180$ & 0.052 & 0.100 & 0.19 \\
\hline $180-240$ & 0.100 & 0.140 & 0.37 \\
\hline $240-300$ & 0.052 & 0.100 & 0.52 \\
\hline $300-400$ & 0.052 & 0.100 & 0.27 \\
\hline $400-500$ & 0.072 & 0.140 & 0.27 \\
\hline $500-600$ & 0.100 & 0.100 & 0.27 \\
\hline $600-750$ & 0.100 & 0.100 & 0.27 \\
\hline
\end{tabular}

\section{Shock}

The shock data presented were obtained during the same shipment as the vibration data but from specific, identifiable events. These data were obtained when the instrumented rail car experienced run-in and run-out as well as when it crossed rail switches, road crossings, bridges, and highway underpasses. Since the instrumented rail car was equipped with hydraulic end-of-car devices, run-in events were insignificant. Run-out events were much more noticeable to the SNL personnel in the adjacent caboose as well as on the data tapes.

When the summarized shock response spectra were overlayed and the peak and mean plus three standard deviation envelopes were examined, it was found that the transverse axis had the lowest response amplitude over most of the $0.5-$ to $750-\mathrm{Hz}$ frequency range. The vertical axis response amplitude envelopes were generally equal to or slightly higher than the other two axes; however, the longitudinal axis response amplitudes were higher than the other two axes in the very low frequency between 0.5 and $1.5 \mathrm{~Hz}$ and again in the 80 to about $180 \mathrm{~Hz}$ range. Figure 7 shows the shock response spectra envelopes which envelop the peak and mean plus three standard deviation response spectra. 


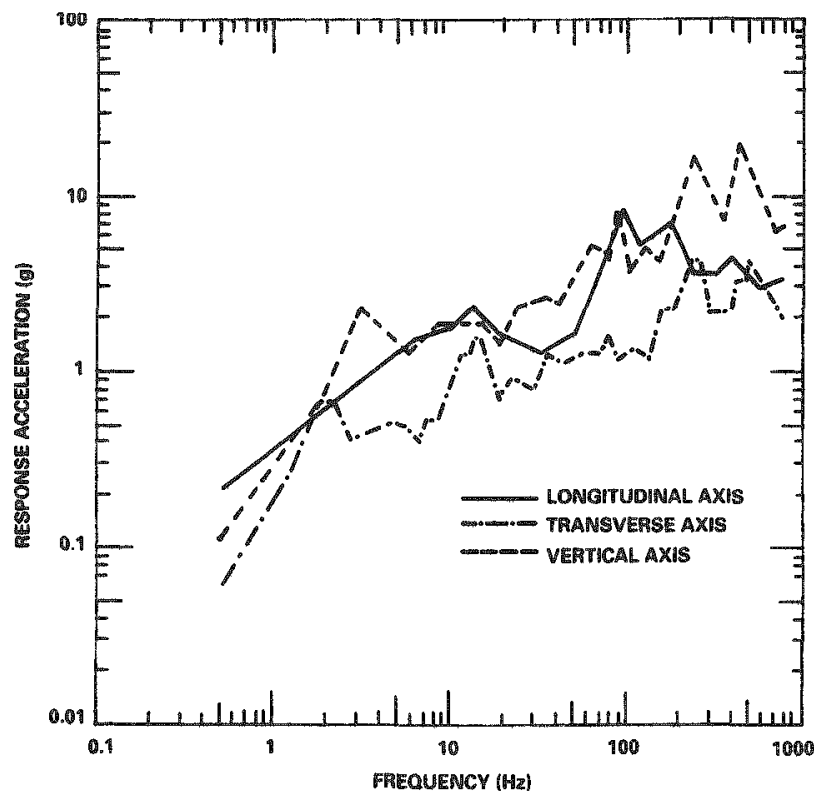

Figure 7. Mean Plus Three Standard Deviation Amplitude Envelopes of Shock Response Spectra; $3 \%$ Damping

\section{References}

${ }^{1}$ C. F. Magnuson and L. T. Wilson, Shock and Vibration Environments for Large Shipping Containers on Rail Cars and Trucks, SAND76-0427 (Albuquerque: Sandia Laboratories, July 1977).
${ }^{2}$ C. F. Magnuson, Shock and Vibration Environments for Large Shipping Container During Truck Transport (Part 1), SAND77-1110 (Albuquerque: Sandia Laboratories, September 1977).

${ }^{3} \mathrm{C}$. F. Magnuson, Shock and Vibration Environments for a Large Shipping Container During Truck Transport (Part II), SAND78-0337 (Albuquerque: Sandia Laboratories, May 1978).

${ }^{4} \mathrm{C}$. F. Magnuson, Shock Environments for Large Shipping Containers During Rail Coupling Operations, SAND79-2168 (Albuquerque: Sandia National Laboratories, June 1980).

${ }^{5}$ R. C. Rentzsch, In Situ Environmental Sampler Data Acquisition System, SAND78-0046 (Albuquerque: Sandia Laboratories, January 1979).

T. E. Smart, Operation and Maintenance Documentation for Program VIBR.AND, SLA-73-0616 (Albuquerque: Sandia Laboratories, October 1973).

7L. A. Faw, Program VAIL (User's Manual), SC-M-71 0709 (Part 1) (Albuquerque: Sandia Laboratories, November 1971).

8. E. Beisinger, Modification of ZSHAIL Program, Informal Memorandum (Albuquerque: Sandia Laboratories, August 21, 1979). 
Atchison, Topeka, and Santa Fe Railway Co.

80 East Jackson Blvd

Chicago, IL 60604

Attn: D. G. Ruegt

Atchison, Topeka, and Santa Fe Railway Co. Motive Power Building

1001 NE Atchison St

Topeka, KS 66616

Attn: W. H. Clark

Atchison, Topeka, and Santa Fe Railway Co.

Box 987

1st and Cook Sts

Raton, NM 87740

Attn: H. C. Powers

Atchison, Topeka, and Santa Fe Railway Co. 402 Santa Fe Ave

La Junta, CO 81050

Attn: S. L. Fruin

Atchison, Topeka, and Santa Fe Railway Co.

PO Box 1477

West 4th St R.R. Yards

Pueblo, CO 81002

Attn: F. L. Sparks

Atchison, Topeka, and Santa Fe Railway Co. 214 First St SW

Albuquerque, NM 87102

Attn: W. N. Spears

Allied General Nuclear Services

PO Box 847

Barnwell, SC 29812

Attn: R. T. Anderson

American Association of Railroads

1920 L St NW

Washington, DC 20036

Attn: C. P. Furber

American Trucking Association, Inc

1616 P St NW

Washington, DC 20036

Attn: R. M. Doyle

Argonne National Laboratory

PO Box 2528

Idaho Falls, ID 83401

Attn: C. S. Abrams
Argonne National Laboratory

9700 South Cass Ave

Argonne, IL 60439

Attn: C. J. Roberts

Atomic Industrial Forum

7101 Wisconsin Ave

Bethesda, MD 20014

Attn: E. Gordan

Battelle Memorial Institute

Columbus Laboratory

505 King Ave

Columbus, OH 43201

Attn: D. R. Ahlbeck

Battelle Memorial Institute

Columbus Laboratory

505 King Ave

Columbus, OH 43201

Attn: C. C. Kimm

Battelle Memorial Institute

Office of Nuclear Waste Isolation

505 King Ave

Columbus, OH 43201

Attn: R. W. Peterson

Battelle Memorial Institute

Pacific Northwest Laboratory

PO Box 999

Richland, WA 99352

Attn: K. J. Schneider

Brookhaven National Lab, NS Lib (DOE)

Brookhaven National Laboratory

Department of Nuclear Energy, Bldg 30

Upton, NY 11973

Attn: Nuclear Safety Library

Chem-Nuclear Systems, Inc

PO Box 726

Barnwell, SC 29812

Attn: D. Ebenhack, Manager

Health and Safety

Chem-Nuclear Systems, Inc

PO Box 1866

Bellevue, WA 98009

Attn: L. E. Reynolds,

Corporate Director of Regulatory Affairs 
DISTRIBUTION (cont):

Edlow International Co. 110017 th St NW, Suite 404

Washington, DC 20036

Attn: J. Edlow

\section{EG\&G}

Idaho National Engineering Laboratory

PO Box 1625

Idaho Falls, ID 83415

Attn: T. H. Smith, TRU

E. I. duPont de Nemours and Company, Inc Savannah River Plant

Aiken, SC 29801

Attn: Technical Library

Electric Power Research Institute

PO Box 10412

Palo Alto, CA 94303

Attn: R. E. Nickell

Energy Research Group, Inc

400-1 Totten Pond Rd

Waltham, MA 02154

Attn: J. L. Murphy

Federal Emergency Management Agency 1725 Eye St NW

Washington, DC 20472

Attn: J. D. Winkle, Director

Federal Response Coordination

General Atomic Co.

PO Box 81608

San Diego, CA 92138

Attn: R. Burgoyne

International Energy Associates, Ltd

600 New Hampshire Ave NW

Washington, DC 20037

Attn: M. Elliott

Lawrence Livermore Lab (DOE)

University of California

Lawrence Livermore Laboratory

PO Box 5500

Livermore, CA 94557

Attn: Technical Information Dept, L-53
Library of Congress

CRS-ENGR

Washington, DC 20540

Attn: C. Behrens

Los Alamos National Laboratory (2)

PO Box 1663

Los Alamos, NM 87545

Attn: J. L. Warren

T. A. Butler, WX8

Morgan State University

Center for Transportation Studies

Baltimore, MD 21239

Attn: R. P. Capelle, Jr

Mound Laboratory (DOE)

Monsanto Research Corp

Mound Lab

PO Box 32

Miamisburg, OH 45342

Attn: Library

National Academy of Sciences

Committee on Radioactive Waste Mgmt

2101 Constitution Ave NW

Room JH-826

Washington, DC 20418

National Highway Transportation Safety

Administration

4007 th St SW

Washington, DC 20590

National Research Council

Transportation Research Board

2101 Constitution Ave NW

Washington, DC 20418

National Tank Truck Carriers, Inc

1616 P St NW

Washington, DC 20036

Attn: C. J. Harvison

National Transportation Safety Board

TE-40

Washington, DC 20594

Attn: L. Benner 
New England Nuclear Corp 601 Treble Cove Rd

North Billerica, MA 01862

Attn: E. DeMaria

Northeast Utilities

PO Box 270

Hartford, CT 06101

Attn: R. W. Bishop

Secretary and Counsel

NUS Corp

4 Research Place

Rockville, MD 20850

Attn: N. B. McLeod

Nuclear Assurance Corp

24 Executive Park West

Atlanta, GA 30329

Attn: C. Thorup, Vice President

Oak Ridge National Laboratory (2)

PO Box X

Oak Ridge, TN 37830

Attn: C. Fore

L. B. Shappert

Rockwell International

Atomics International Division

Rocky Flats Plant

PO Box 464

Golden, CO 80401

Attn: W. S. Bennett

Rockwell International

PO Box 800

Richland, WA 99352

Attn: M. Bensky

The S. M. Stoller Corp

Colorado Bldg, Suite 800

Boulder, CO 80302

Attn: M. H. Raudenbush

Southern States Energy Board

One Exchange Place, Suite 1230

Atlanta, GA 30338

Attn: Library
State of New Mexico

Division of Health and Environment

PO Box 968

Santa Fe, NM 87503

Attn: A. Topp

Stearns-Roger Manufacturers, Inc (2)

Box 5888

4500 Cherry Creek Dr

Denver, CO 80217

Attn: R.W. Cecil

J. Lewis

Transnuclear, Inc

One North Broadway

White Plains, NY 10601

Attn: W. Teer

The Transport Environment

SR 285 Old Squaw Dr

Kitty Hawk, NC 27949

Attn: W. Brobst, President

Thomas Gray Associates

815 N Main St

Orange, CA 92668

Attn: T. Gray, President

Tri-State Motor Co.

PO Box 113

Joplin, MO 64801

Attn: C. H. Mayer, Vice President Nuclear Division

Union Carbide Corp

270 Park Ave

New York, NY

Attn: S. Hoffman, Esq

Transportation Counsel

US Department of Energy

San Francisco Operations Office

1333 Broadway

Oakland, CA 94612

Attn: Traffic Manager

US Department of Energy

Rocky Flats Area Office

PO Box 298

Golden, CO 80401

Attn: D. M. Krieg, Traffic Manager 
DISTRIBUTION (cont):

US Department of Energy (2)

Office of Nuclear Energy

Washington, DC 20545

Attn: E. Jordan, NE-320

E. F. Mastel, NE-313

US Department of Energy

Washington Library

Washington, DC 20545

Attn: Energy Library

US Department of Energy (3)

Idaho Operations Office

550 Second St

Idaho Falls, ID 83401

Attn: R. Long, Traffic Manager

S. Vorndran, Actg Program Manager West Valley Project

J. Whitsett, Chief

Radioactive Waste Mgmt Branch

US Department of Energy

Chicago Operations Office

9800 South Cass Ave

Argonne, IL 60439

Attn: G. Ishmael, Traffic Manager

US Department of Energy

NWTS National Program Office

Columbus, OH 43201

Attn: J. O. Neff

US Department of Energy (6)

Albuquerque Operations Office

Albuquerque, NM 87115

Attn: R. H. Campbell

J. P. Crane, Director Transp Safeguards Division

E. C. Hardin, Jr, Actg Deputy

Asst Mgr, Office of Projects and

Energy Programs

W. C. Purchase, Traffic Manager

IK. Carlson

R. Y. Lowrey

US Department of Energy

Nevada Operations Office

PO Box 14100

Las Vegas, NV 89114

Attn: A. Neumann, Traffic Manager
US Department of Energy

Brookhaven Area Office

Upton, NY 11973

Attn: Traffic Manager

US Department of Energy (2)

Dayton Area Office

PO Box 66

Miamisburg, $\mathrm{OH} 45342$

Attn: R. U. Blauvelt Traffic Manager

US Department of Energy

Savannah River Operations Office

PO Box A

Aiken, SC 29801

Attn: L. Turner, Traffic Manager

US Department of Energy

Oak Ridge Operations Office

PO Box E

Oak Ridge, TN 37830

Attn: L. Blalock, Traffic Manager

US Department of Energy

Richland Operations Office

PO Box 999

Richland, WA 99352

Attn: J. Peterson, Traffic Manager

US Department of Transportation (4)

400 Seventh St SW

Washington, DC 20590

Attn: D. Crockett, DMT-1, Rm 8102

R. R. Rawl, MTB

L. Santman

D. Dancer

US Environmental Protection Agency

$401 \mathrm{M} \mathrm{St} \mathrm{NW}$

Washington, DC 20460

Attn: R. Clark

US Nuclear Regulatory Commission (7)

Washington, DC 20555

Attn: K. Black, M/S 7217 MNB

N. L. Eisenberg, M/S NL-5650

D. R. Hopkins, M/S NL-5650

C. E. MacDonald, M/S 396-SS

D. O. Nellis, M/S NL-5650

W. R. Lahs, SAFER Division

J. C. Malaro, M/S NL-5650 
US Department of Energy (6)

Nuclear Energy

Routing NE-340

Washington, DC 20545

Attn: G. Oertel

D. McGoff

F. P. Falci

R. F. Garrison

J. A. Sisler

T. Anderson

Westinghouse Hanford Co.

Hanford Engineering Development Lab

PO Box 1970

Richland, WA 99352

Attn: S. R. Fields

1000 J. K. Galt

1200 G. Yonas

1500 J. K. Galt (actg)

1510 D. B. Hayes

1520 T. B. Lane

Attn: R. D. Kreig

T. G. Priddy

L. W. Davison

1523 R. C. Reuter, Jr.

1523 C. F. Magnuson (40)

1530 W. Herrmann

3743 C. Summers

Attn: C. R. Freund
7000 O. E. Jones

7500 W. A. Gardner

7520 T. J. Hoban

Attn: G. L. West, 7522

8000 R. S. Claassen

9000 G. A. Fowler

9210 V. E. Blake, Jr.

Attn: J. T. Risse, 9213

M. R. Madsen, 9214

9300 R. L. Peurifoy, Jr.

9400 A. W. Snyder

9700 E. H. Beckner

Attn: W. D. Weart, 9730

R. W. Lynch, 9760

9780 R. M. Jefferson

Attn: TTC Master File

9780 E. W. Shepherd

9780 TTC Library, File Ref No. 3002.030 (3)

9781 R. E. Luna

9782 R. B. Pope

9782 J. M. Ortman

9782 A. A. Trujillo (5)

9783 G. C. Allen, Jr.

9783 M. G. Vigil

9783 H. R. Yoshimura

8214 M. A. Pound

3141 L. J. Erickson (5)

3151 W. L. Garner (3)

3154-3 C. H. Dalin (25)

For DOE/TIC (Unlimited Release) 